\title{
Porosphaera globularis (Phillips, 1829) (Porifera, Calcarea) in the Campanian (Upper Cretaceous) of extra-Carpathian Poland
}

\author{
AGATA JURKOWSKA ${ }^{1}$, EWA ŚWIERCZEWSKA-GLADYSZ ${ }^{2}$, ZOFIA DUBICKA ${ }^{3}$, \\ DANUTA OLSZEWSKA-NEJBERT ${ }^{3}$ \\ ${ }^{1}$ Institute of Geological Sciences Jagiellonian University, Oleandry 2a St. PL-30-063 Kraków, Poland \\ (current address) Faculty of Geology, Geophysics and Environmental Protection AGH, \\ University of Science and Technology, Mickiewicza 30, PL-30-059 Kraków, Poland. \\ E-mail: jurkowska.a@gmail.com \\ ${ }^{2}$ Institute of Earth Sciences, University of Lodz, ul. Narutowicza 88 St., PL-90-139 Lódź, Poland. \\ E-mail: eswiercz@geo.uni.lodz.pl \\ ${ }^{3}$ Institute of Geology, University of Warsaw, al. Żwirki i Wigury 93, PL-02-089 Warszawa, Poland. \\ E-mails: z.dubicka@uw.edu.pl,don@uw.edu.pl
}

\begin{abstract}
:
Jurkowska, A., Świerczewska-Gładysz, E., Dubicka, Z. and Olszewska-Nejbert, D. 2015. Porosphaera globularis (Phillips, 1829) (Porifera, Calcarea) in the Campanian (Upper Cretaceous) of extra-Carpathian Poland. Acta Geologica Polonica, 65 (1), 121-139. Warszawa.

The stratigraphical distribution of Porosphaera globularis, a common calcareous sponge in the Upper Cretaceous (mostly Campanian and Maastrichtian) of Poland was studied. The presented material, both new and from museum collections, comes from the Campanian of the Miechów Synclinorium, in southern Poland, and from the Lower Campanian of Mielnik in the south-eastern part of the Mazury-Podlasie Homocline, in eastern Poland. The significance of the species in extra-regional correlation, its palaeobiogeography and stratigraphical potential is critically reviewed.
\end{abstract}

Key words: Porosphaera globularis; Calcareous sponges; Campanian; extra-Carpathian Poland.

\section{INTRODUCTION}

During stratigraphical studies of the Campanian-Maastrichtian succession of the Miechów Synclinorium the senior author (AJ) noticed that Porosphaera globularis occurs only in certain in- tervals, while absent in others. The aim of this paper is to document the detailed stratigraphical distribution of $P$. globularis and test its stratigraphical potential, based on extensive material (both historical and newly collected) from the Campanian of extraCarpathian Poland. 
In Poland, P. globularis is known so far from the uppermost Santonian through the Campanian. Its presence in the Campanian was first mentioned by Bieda (1933), based on specimens from the lower Campanian of Bonarka (now within the town limits of Kraków) (see also Barczyk 1956). Hurcewicz (1960) reported the species from various localities in the Kraków area. Later, Hurcewicz (1966) and Małecki (1989) reported it from the Lower Campanian of an area farther to the north. Apart from these localities, all within the Miechów Synclinorium, P. globularis was also noted from the white chalk of Mielnik and Kornica, two localities in east-central Poland (Olszewska 1987; Langner 1990; Olszewska-Nejbert and ŚwierczewskaGładysz 2011).

Porosphaera globularis (Phillips, 1829) belongs to the small, calcareous sponges of the family Minchinellidae Dendy and Row, 1913 (order Lithonida Vacelet, 1981) possessing a skeleton consisting of linked and cemented spicules, which gives them an extremely high preservation potential. P. globularis is one of the most common members of the family, and it occurs abundantly in the Upper Cretaceous of Europe in both its western (Hinde 1904; Termier and Termier 1985a, 1985b; Wood 2002; Lepage and Lepage 2011) and central (e.g. Frič 1889; Wollemann 1901; Nestler 1961; Giers 1964) parts. It is also noted from the PeriCaspian, Vol'sk and Khvalynsk Lowlands (Pervushov 1998) and from the Middle East (Wilmsen et al. 2012). Porosphaera globularis first appeared in the Early Cenomanian (Normandy, France after Termier and Termier 1985a) and ranged till the early Paleocene (Danian, Stevns Klint, Denmark, after Bjerager and Surlyk 2007). Its relative abundance in the basal Lower Maastrichtian white chalk 'Porosphaera beds' in the glaciotectonic masses on the Norfolk coast in eastern England has long served as a good marker horizon, at least on a local scale (see Wood 1967; Johansen and Surlyk 1990; Mortimore et al. 2001).

\section{MATERIALS AND METHODS}

The studied material of Porosphaera globularis comes from fourteen sections in the Miechów Synclinorium (Kraków, Miechów and Szczekociny areas; the Bonarka, Pniaki, Iwanowice, Poskwitów, Wierzchowisko, Jeżówka 1, Jeżówka 2, Biała Wielka, Wola Więclawska, Falniów, Poradów, Bibice, Zbyczyce and Komorów sections) and from Mielnik and Kornica, two sections in east-central Poland. The chronostratigraphic position of particular sections studied is based primarily on inoceramid bivalves. Where inoceramids are absent, the stratigraphy is based on foraminifers. Dating of some of the historical outcrops (Bibice, Zbyczyce, Komorów) was possible based on associated museum inoceramid material or archival micropaleontological samples kept with the rest of the palaeontological material.

The studied specimens of $P$. globularis were collected bed by bed from each of the sections. Usually they occur in marls and opokas (siliceous limestones), and are common in specific intervals. These intervals with $P$. globularis were studied in detail.

In total, 161 specimens of $P$. globularis are available for palaeontological study; including both newly collected material and the museum collections of H. Hurcewicz and J. Małecki from the Kraków, Miechów and Szczekociny areas, housed in the University of Lódź. The new specimens are housed in the Laboratory of Geology of the same university (collection nos UL/I and UL/Ia).

Thin sections, small skeleton samples, and photographic analyses were made in the Microscope Laboratory and Microanalysis Laboratory of the University of Warsaw using a Nicon SMZ 1000 stereoscope microscope, a Nicon ECLIPSE E600W POL optical microscope and a JEOL JSM-6380LA scanning electron microscope.

Following Ogg and Hinnov (2012), the tripartite subdivision of the Campanian Stage, is applied herein (see also Jurkowska 2014).

\section{GEOLOGICAL SETTING AND PALAEOGEO- GRAPHY}

The Kraków, Miechów and Szczekociny areas are situated in the Miechów Synclinorium (Text-fig. 1), being a south-eastern segment of the Szczecin-ŁódźMiechów Synclinorium. The Mielnik area is located in the south-eastern part of the Mazury-Podlasie Homocline.

All source localities represent the record of the extensive epicontinental Late Cretaceous Sea of extraCarpathian Poland (Pożaryski 1960; Leszczyński 1997, 2012), which was a part of the North European biogeographic province (Christensen 1976). The topmost Santonian and Campanian of the present-day Miechów Synclinorium (regions of Kraków, Miechów and Szczekociny) was dominated by monotonous carbonate sedimentation (opokas, marly limestones and marls) (Pożaryski 1960; Rutkowski 1965; Walaszczyk 1992, 2004). The Campanian of the Mielnik area is invariably in white chalk facies (Alexandrowicz and Radwan 1992). 


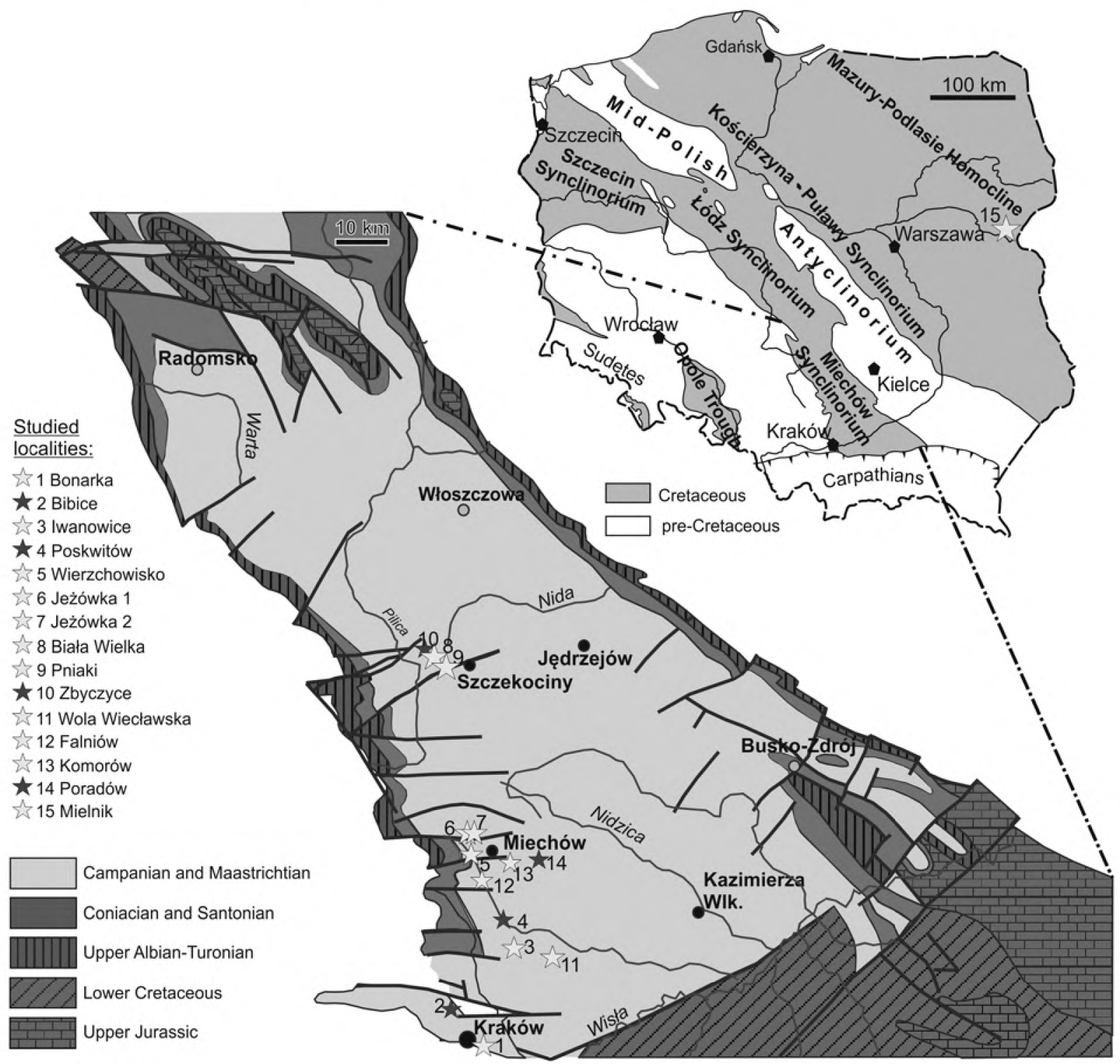

Text-fig. 1. Tectonic sketch-maps of Poland (without the Cenozoic cover) (after Pożaryski 1974; Narkiewicz and Dadlez 2008; and Żelaźniewicz et al. 2011; simplified) and of the Miechów Synclinorium with source localities of Porosphaera globularis (Phillips); recent sites - light-grey stars; historical sites dark-grey stars

\section{Miechów Synclinorium}

Over a dozen $P$. globularis-bearing localities, of the latest Santonian through Campanian, were recognized in the south-western limb of the Miechów Synclinorium (Text-fig. 1).

The Campanian of the area is composed of opoka with marly intercalations. The opoka is represented by wackestone (dominating the Lower Campanian) and packstone (dominating the Middle and Upper Campanian), with planktonic foraminifera and spicules of siliceous sponges. Organodetrital components also com- prise fragments of bivalves and rare echinoderms. There is an insignificant admixture of detrital quartz and glauconite. The opoka is quite fossiliferous, with common sponges (lychniscosids, hexactinosids, lyssacinosids and lithistids), echinoids (Echinocorys and Micraster in opoka, and Offaster and rare Micraster in marl), bivalves and belemnites.

Some of the exposures (e.g. Narama, Miechów, Rudawa, Szczepanowice) listed by Hurcewicz (1960) and Malecki (1989) were impossible to locate. Moreover, in the case of Szczepanowice, it is difficult to state from which outcrop Hurcewicz's 
specimens of $P$. globularis were collected, as at least two distinct villages of Szczepanowice exist. The section of Wola Więcławska lies $2 \mathrm{~km}$ NE of the section of Michalowice described by Małecki (1989). Stratigraphically, the succession of the Michałowice section seems to be an equivalent of the Wola Więcławska section.

In the Miechów Synclinorium, P. globularis seems to be confined to the uppermost Santonian-lower Lower Campanian (Sphenoceramus patootensiformis through to Sphaeroceramus sarumensis-Cataceramus dariensis zones) the middle Campanian ('Inoceramus' azerbaydjanensis/'I.' vorhelmensis Zone to 'I.' temilineatus Zone) and the lowest part of the Upper Campanian (Sphaeroceramus pertenuiformis Zone). The species was found in all of the available sections of these stratigraphical intervals, where it occurs commonly in distinct layers.

All of the 14 localities with $P$. globularis are characterized briefly below (in alphabetical order) (Text-figs 1,2):

Biala Wielka (N 50 41' 17.19"; E $19^{\circ} 39^{\prime} 42.52^{\prime \prime}$ ); working quarry in the Lower Campanian (Cataceramus dariensis-Sphaeroceramus sarumensis) opoka with marly intercalation.

Bibice; historical outcrop of Małecki (1989) and Zapałowicz-Bilan et al. (2009), c. $10 \mathrm{~km}$ north of Kraków. Based on archival collection of inoceramids, the deposit in the outcrop represented the Lower Campanian (Cataceramus dariensis-Sphaeroceramus sarumensis Zone) opoka with cherts.

Bonarka (N 50²'17. 39"; E1957'15.44"); historical, abandoned quarry (nature reserve), now within the limits of the town of Kraków, in the uppermost Santonian and Lower Campanian (upper Sphenoceramus patootensiformis Zone) grey marl and opoka with marly intercalations (see e.g., Smoleński 1906; Panow 1934; Alexandrowicz 1954; Barczyk 1956; Gradziński 1960; Kudrewicz and Olszewska-Nejbert 1997). Apart from some specimens collected by the senior author, $P$. globularis is well represented in the collections of Hurcewicz (1960) and Małecki (1989). The species is abundant in the grey marl and less common in the overlying opoka. A sample from the marl yielded the foraminifera Stensioeina gracilis Brotzen, 'early' Stensioeina pommerana Brotzen and Bolivinoides strigillatus (Chapman), and the zonal index crinoid Marsupites testudinarius, proving its latest Santonian age. The overlying opoka lacks M. testudinarius, and is referred to the earliest Early Campanian.
Falniów (N 50²2'32.54" E 1957'56.35"); natural exposure in the Middle Campanian ('Inoceramus' azerbaydjanensis / 'Inoceramus'vorhelmensis Zone) opoka with marly intercalations. Macrofossils are relatively abundant, dominated by sponges and bivalves; $P$. globularis is recognized in the opokas and marls.

Iwanowice (N 50 11'4. 74"; E 1959'3.43"); natural exposure in eastern part of the village of Iwanowice (Słomniki area) in the Lower Campanian opoka with marly intercalations. Stratigraphical position of the section is documented by foraminifers studied herein. The co-occurrence of Bolivinoides granulatus Hofker, Gavelinella clementiana (d'Orbigny), Stensioeina gracilis Brotzen, Gavelinella stelligera (Marie) and the lack of Cibicidoides voltzianus (d'Orbigny) indicate its middle Early Campanian (an interval from the Offaster pilula/Galeola senonensis echinoid Zone to the $G$. senonensis Zone of Schulz et al. 1984) age. This interval corresponds to the Cataceramus dariensis-Sphaeroceramus sarumensis inoceramid Zone of Walaszczyk (1997). P. globularis is relatively abundant, mainly in the marls. Some specimens come from the Małecki collection.

Jeżówka 1 (N 50²4'41.37"; E 1950'12.42"); abandoned quarry in the Lower Campanian opoka. The lower part of the section (below the hardground) represents the Cataceramus dariensis-Sphaeroceramus sarumensis Zone. The opoka above the hardground belongs to the upper part of the Cataceramus beckumensis Zone (see Jagt et al. 2004). Marly horizons with numerous $P$. globularis are $2 \mathrm{~m}$ below the hardground.

Jeżówka 2 (N 50²4'50.98"; E 1949'4.43"); natural exposure in the Lower Campanian opoka with cherts and marly intercalations. The lower, $2 \mathrm{~m}$ thick part of the succession represents the upper part of the Sphenoceramus patootensiformis Zone. Two samples, collected 3 and $4 \mathrm{~m}$ above the base of the section respectively, yielded the biostratigraphically important foraminifers Gavelinella clementiana, Gavelinella stelligera, Stensioeina gracilis and Bolivinoides granulatus, dating this part of the succession as middle Early Campanian (Offaster pilula/Galeola senonensis echinoid Zone to the $G$. senonensis Zone). This interval corresponds to the inoceramid zone of Cataceramus dariensis-Sphaeroceramus sarumensis (Walaszczyk 1997). P. globularis was collected throughout the succession, mainly from the marly intercalations. 
POROSPHAERA GLOBULARIS (PORIFERA) FROM THE CRETACEOUS OF POLAND

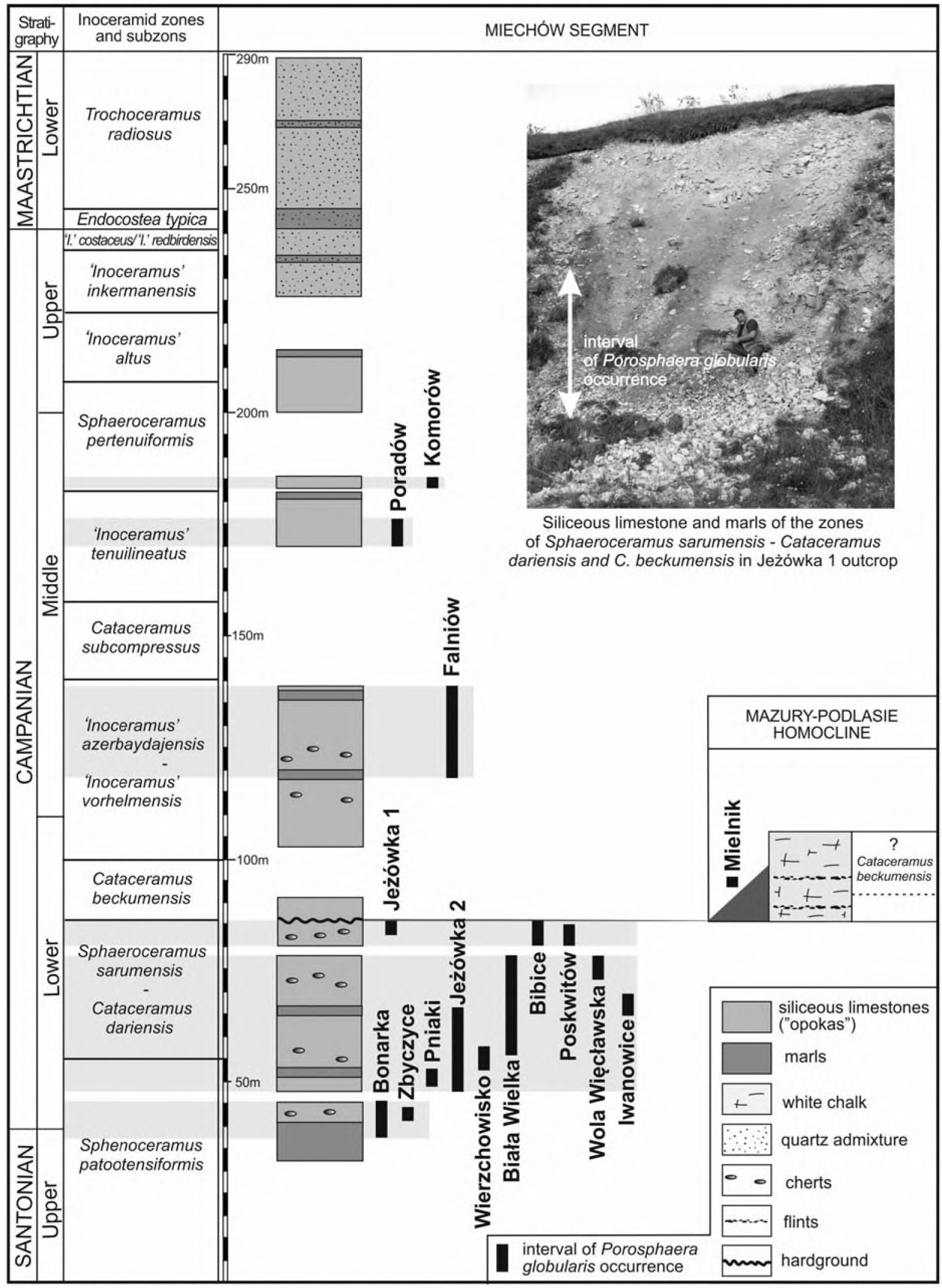

Text-fig. 2. Geological columns of the Upper Santonian - Lower Maastrichtian of the Miechów Synclinorium (stratigraphy after Jurkowska 2014), and of the Campanian in Mielnik, in the Mazury-Podlasie Homocline with ranges of Porosphaera globularis (Phillips, 1829). Outcrops location see Text-fig. 1 
Komorów; locality of Hurcewicz (1960; and probably of Rutkowski 1965), near Miechów. Based on inoceramids the section represents the basal Upper Campanian Sphaeroceramus pertenuiformis inoceramid Zone.

Pniaki (N 50 41' 17.19"; E 19³9' 42.52"'); abandoned quarry in the Lower Campanian opoka with thin marly intercalations. Only the upper part of the section is currently available for research. The precise stratigraphical position of the section is based on newly studied foraminifera. The species present comprised Bolivinoides granulatus, Gavelinella stelligera and Stensioeina gracilis, an assemblage which indicates the middle Lower Campanian.

Poradów (N 50²0'5.12"; E 20³'5.95"); natural exposure in the Middle Campanian marly opoka with marly intercalations. The following newly obtained foraminifers, Globorotalites hiltermanni Kaever, Globorotalites michelinianus (d'Orbigny), Gavelinella monterelensis (Marie) and Coryphostoma incrassata (Reuss), date the succession as belonging to the 'Inoceramus' tenuilineatus Zone of the late Middle Campanian. P. globularis is common in the marly intercalations.

Poskwitów; outcrop of Mączyńska (1968; described also by Kudrewicz and Olszewska-Nejbert 1997) of Lower Campanian marl and marly opokas with cherts.

The newly studied foraminiferal samples from the Poskwitów section yielded: Gavelinella stelligera, Stensioeina gracilis; S. pommerana and Bolivinoides decoratus (Jones). These taxa indicate the Bolivinoides decoratus decoratus Zone sensu Koch, 1977 (the upper part of the Lower Campanian). This zone corresponds to the upper part of the Sphaeroceramus sarumensis-Cataceramus dariensis inoceramid Zone (Walaszczyk 1997). P. globularis is relatively common throughout the succession, particularly in the marls.

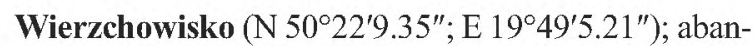
doned quarry in the Lower Campanian (upper Sphenoceramus patootensiformis and lower Cataceramus dariensis-Sphaeroceramus sarumensis inoceramid Zones; see Jagt et al. 2004) opoka with cherts and marly intercalations.

Wola Więclawska (N 50¹0'51.67"; E 200'58.61"); natural exposure in the Lower Campanian (Cataceramus dariensis-Sphaeroceramus sarumensis inoceramid Zone) opoka with marly intercalations, and common $P$. globularis, mainly in the marly intercalations.
Zbyczyce; outcrop of Lower Campanian opoka of Hurcewicz (1966). Newly studied foraminiferal sample yielded Bolivinoides culverensis Barr, Stensioeina gracilis, Gavelinella stelligera and Globotruncana arca (Cushman). This assemblage and the lack of Gavelinella clementiana indicate the lowermost Campanian Gonioteuthis granulaquadrata belemnite Zone (see Schönfeld 1990), which corresponds to the upper part of the Sphenoceramus patootensiformis inoceramid Zone (Walaszczyk 1997).

\section{Mazury-Podlasie Homocline}

Mielnik (N 52 $19^{\prime} 47.49^{\prime \prime}$; E 233'5.38"); large working quarry with an exposed succession of Campanian and Maastrichtian white chalk (Gaździcka 1981; Peryt 1981; Olszewska 1990; Olszewska-Nejbert and Świerczewska-Gładysz 2011). P. globularis was found in the middle part of the succession, $2-3 \mathrm{~m}$ below the upper of the two flints horizons (Text-fig. 2). According to O1szewska-Nejbert and Świerczewska-Gładysz (2011), this part of the succession represents the upper part of the Lower Campanian (undivided belemnite zones of Goniotheutis gracilis + Belemnellocamax mammilla$t u s)$. The foraminiferal samples from this part of the succession yielded: Cibicidoides voltzianus, Gavelinella 'post' stelligera, Gavelinella clementiana, Gavelinella costulata (Marie), Bolivinoides decoratus, and Bolivinoides laevigatus. This assemblage indicates the lowerupper Campanian boundary interval (Koch 1977; Hart et al. 1989; Schönfeld 1990), corresponding to the Cataceramus beckumensis inoceramid Zone (Walaszczyk 1997).

Porosphaera globularis was also noted in Kornica (historical outcrop located about c. $15 \mathrm{~km}$ south of Mielnik) by Langner (1990) probably in the same interval as Mielnik, but detailed stratigraphical data are not available.

\section{SYSTEMATIC ACCOUNT}

Class: Calcarea Bowerbank, 1864

Order: Lithonida Doederlein, 1892

Family: Minchinellidae Dendy and Row, 1913

Genus Porosphaera Steinmann, 1878

TYPE SPECIES: Millepora globularis Phillips, 1829, p. 186 , pl. 1 , fig. 12 , by monotypy.

Porosphaera globularis (Phillips, 1829)

(Text-figs 3-6) 
1829. Millepora globularis; J. Phillips, p. 186, pl. 1, fig. 12. 1878. Porosphaera globularis (Phillips); G. Steinmann, p. 102, pl. 13, figs 8-12.

1889. Amorphospongia globosa v. Hag. sp.; A. Frič, p. 108, fig. 52.

1901. Porosphaera globularis (Phillips); A. Wolleman, p. 10-11.

1903. Porosphaera globularis Reuss sp; F. Počta, p. 8-10, pl. 1, figs 4-12; text-fig. 1.

1904. Porosphaera globularis (Phillips); G.J. Hinde, p. 18 , pl. 1, figs 1-10, pl. 2, figs 1-3, 6-10.

1960. Porosphaera globularis (Phillips); H. Hurcewicz, pp. 438-444, text-fig. 1-3, pl. 1, fig. 1-29, pl. 2, figs 1 2 [with synonymy].

1961. Porosphaera globularis (Phillips); H. Nestler, p. 39, pl. 10, pl. 11, figs 1-8 [with additional synonymy].

1961. Porosphaera nuciformis (Hagenow); H. Nestler, pp. 43-44, pl. 11, fig. 10.

1964. Porosphaera globularis (Phillips); R. Giers, p. 223.

1974. Porosphaera globularis (Phillips); H. Ulbrich, p. 70.

1986. Porosphaera globularis (Phillips); H.H. Stühmer et al., pl. 3, 4, 6 .

1989. Porosphaera globularis (Phillips); H. Hurcewicz, p. 235 , pl. 145 , figs $8-10$.

1989. Porosphaera globularis (Phillips); J. Małecki, p. 206, text-pl. 1, figs 1-5; pl. 2, figs 1-6; pl. 1, figs 2-17; pl. 2, figs 1-7; pl. 3, figs 1-6; pl. 4, figs 1-5. p. 206-215.

1989. Porosphaera nuciformis (Hagenow); J. Malecki, p. 216, pl. 1 , fig. 1.

1990. Porosphaera globularis (Phillips); E. Langner, p. 39, pl. 4, figs 1-5.

2012. Porosphaera globularis (Phillips); M. Wilmsen et al., pp. 92-94, figs 4, 5 [with additional synonymy].

2014. Porosphaera globularis (Phillips); T. Hansen and F. Surlyk, fig. 4.1.

TYPE: Phillips (1829) did not indicate the holotype of his new species Millepora globularis, however, the original of his illustrated specimen (Phillips 1829, pl. 1, fig. 12), from the topmost Santonian (see Wilmsen et al. 2012) of Dane's Dyke (Yorkshire Coast, eastern England), following Hinde (1904) should be housed in the York Museum. According to recent information from Sarah King, the curator of this Museum, their collections do indeed contain the specimen in question; the label accompanying it reads: Millepora globularis Phillips, Holotype: YM 26, Cretaceous, Chalk; Danes Dyke. Phillips 1829, pl. I, fig.12. Ed. 3 (1875) as Coscinopora globularis. According to Pyrah (1976), however, this specimen does not match the Phillips' illustrated specimen, and we fully agree with this statement, based on illustrations of it sent to us by Sarah King. It therefore appears that specimen YM 26 was never illustrated and/or described, although it most probably comes from
Phillips' original collection. The present location of the Phillips' (1829) illustrated specimen is unknown.

MATERIAL: 38 specimens from Bonarka, 6 specimens from Bibice, 18 specimens from Iwanowice, 7 specimens from Poskwitów, 3 specimens from Wierzchowisko, 8 specimens from Jeżówka 1, 4 specimens from Jeżówka 2, 15 specimens from Biała Wielka, 24 specimens from Zbyczyce, 8 specimens from Wola Więcławska, 6 specimens from Falniów, 15 specimens from Komorów, 4 specimens from Poradów, 5 specimens from Mielnik.

DESCRIPTION: The specimens studied vary in shape (Text-fig. 3). These from the opoka of the Miechów Synclinorium are spherical, loaf-like or pearl-like, usually small, $10-15 \mathrm{~mm}$ in diameter. The larger specimens, up to $20-25 \mathrm{~mm}$ in diameter, are rare and usually less regular. In two atypical specimens from Bonarka (Textfig. $\left.3 \mathrm{~A}_{2}, \mathrm{~A}_{3}\right)$ and one from Iwanowice, the outer (younger) layer of the skeleton is developed asymmetrically and the inner (older) part of a skeleton is visible on one side. Among the material from the marly facies of the Miechów Synclinorium, rhomboidal, triangular and flattened specimens, $9-15 \mathrm{~mm}$ in size, are frequent. Specimens from the white chalk of Mielnik are rounded, oval or very irregular (Text-fig. 301-O6), relatively large, up to $30 \mathrm{~mm}$ in diameter (Text-fig. 303). The outer surfaces of the specimens are covered by small pores, $0.15-0.3 \mathrm{~mm}$ in diameter. Shallow radial grooves, around the narrow site, were noted in only two pearl-like specimens.

All of the specimens are calcitized (Text-figs 4-6) and some of the specimens from Mielnik are partly silicified (Text-fig. $4 \mathrm{E}, \mathrm{F}$ ). The best preserved is usually the outer layer of the basal skeleton, c. $1 \mathrm{~mm}$ thick, especially in specimens from the white chalk of Mielnik (Text-figs 5A-D, 6B-D). This portion of the basal skeleton is composed of linked tetractines, the actines of which are up to $0.1 \mathrm{~mm}$ long and $0.04-0.05 \mathrm{~mm}$ wide. The free apical actines of teractines are damaged, without tips. The internal radial structure of the basal skeleton was observed in only a few specimens (Textfig. 6A). In these specimens, mutually cemented tetractines forming radial skeletal fibres are partly masked by late sparry calcite, which fills the skeletal interspaces (Text-figs 4, 6A, E-F). Locally, the central part of the tetractines is discernible whereas the distal part of the actines and zygosis is not visible (Text-figs $4,6 \mathrm{~A}, \mathrm{E}, \mathrm{F})$. In specimens from opoka, the late calcite infills almost the entire interspicular space of the skeleton and the spicules are completely unrecognizable (Text-fig. 4D). 

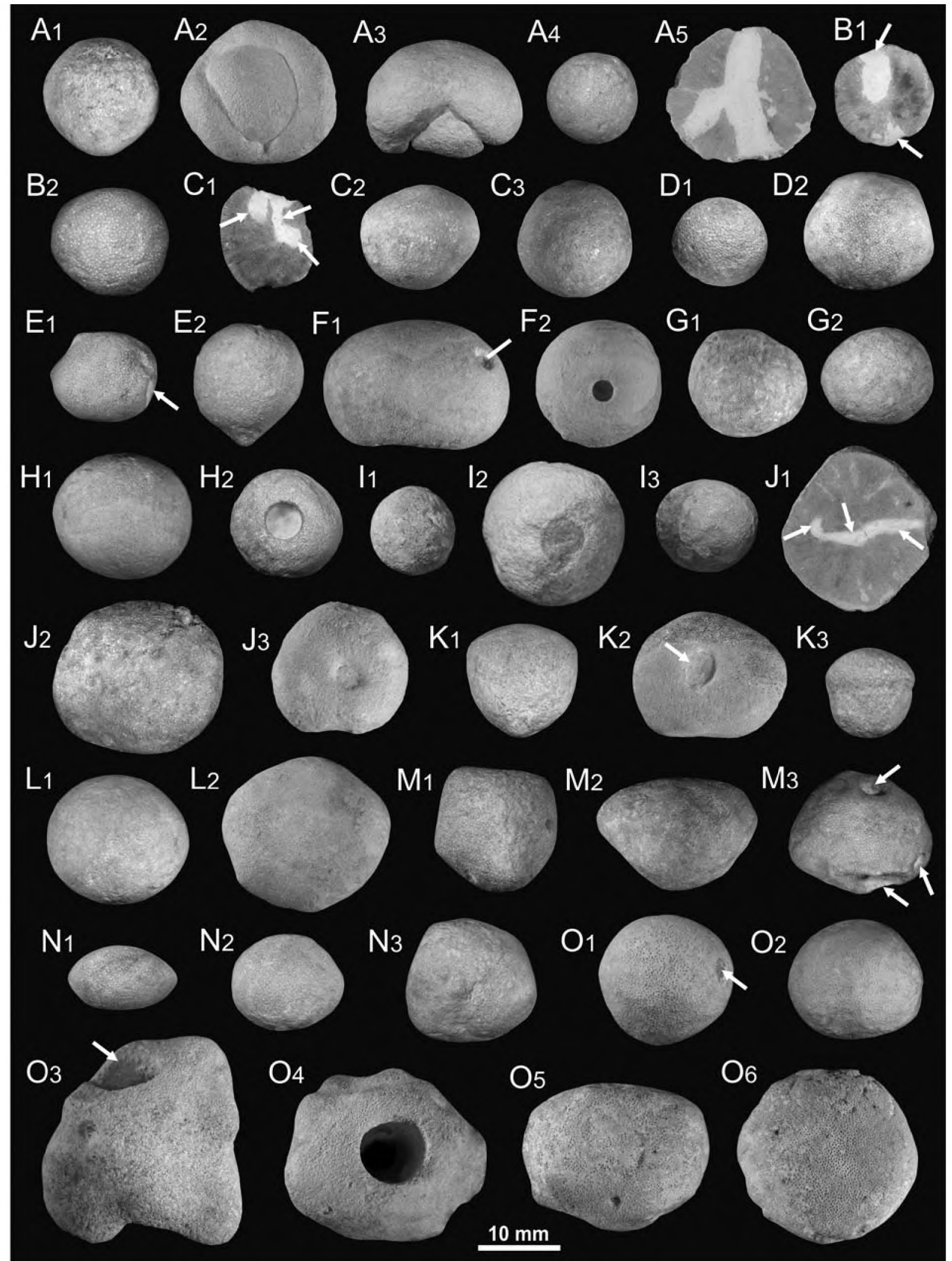
REMARKS: Porosphaera globularis from the Kraków and Miechów areas was described by Hurcewicz (1960) and Małecki (1989), and those from the white chalk of Kornica by Langner (1990); specimens from Mielnik have not yet been studied.

The shape of specimens from the Campanian of Poland is very variable, but falls within the range of variability of $P$. globularis (e.g. Hinde 1904; Nestler 1961). Less regular specimens are more common in marl than in opoka (cf. Hurcewicz 1960), and are also common in white chalk. Rare, irregularly-shaped specimens, with the outer layer of the skeleton asymmetrical or incomplete, were noted earlier by Hurcewicz (1960, pl. 1 fig. 28) and Małecki (1989, pl. 2 fig. 6). The presence of such forms may be due to regeneration. Hurcewicz (1960, p. 441, pl. I, figs 25, 26) reported specimens with irregular grooves, often intersecting each other. In our experience, specimens with similar grooves or irregular pits were found only to occur in the talus and not in the fresh rock. This sculpure is thus not a characteristic feature of the sponges but results from damage due to weathering.

The arrangement of the skeletal fibres in the specimens studied is always radial, similar to that in specimens described elsewhere (e.g. Frič 1889; Hinde 1904; Nestler 1961; Wilmsen et al. 2012). However, Hurcewicz (1960), besides specimens with radial structures of the skeleton (her p. 441, pl. 2, fig. 1), also described specimens characterized by a large central core without radial structure (see Hurcewicz 1960, p. 441, pl. 2, fig. $2 \mathrm{a}, \mathrm{b}$ ). It seems that the presence of a central core could have been a result of improper orientation of the plane of the thin-section. In cross-sections which do not pass through the centre of the sponge, the radial skeletal fibres are perpendicular or nearly perpendicular to the plane of the sections and their radial arangament is not visible.

Małecki (1989, pl. 1, figs. 3, 4) illustrated tetractines from the inner part of the skeleton of $P$. globularis that were identical to spicules described by Hinde (1904). The distal parts of actines and the spines on the apical actines of tetractines illustrated by Malecki (1989, pl. 1, fig. $4 a-c)$, were not observed in the material examined, including specimens from Małecki's own collection. Due to strong calcitization, the central part of tetractines is recognized only sporadically, similar to the spicules described by Hurcewicz (1960, fig. 1-3) and Wilmsen et al. (2012, fig. 5E-G).

Hurcewicz (1960) and Wilmsen et al. (2012) included specimens with shallow radial furrows on the outer surface of the basal skeleton in $P$. globularis. On the other hand, Malecki (1989) and Nestler (1961) referred such specimens to Porosphaera nuciformis (Hagenow). The differences between $P$. globularis and $P$. nuciformis are not clear. According to Hinde (1904), the latter species is characterized by the presence of star-like furrows (see Hinde 1904, p. 20-21, pl. 1, figs 11-18, pl. 2, fig. 4), but shallow grooves may also occur in P. globularis (see Hinde 1904, pl. 1, figs 9-10). Other features unique to $P$. nuciformis are not known. Wilmsen et al. (2012) noted that $P$. nuciformis (Hagenow) was very rare and that it seemed to be identical in terms of stratigraphical and geographical ranges to $P$. globularis. Part of the specimens from the Campanian of Spain classified by Küchler (2000) as P. nuciformis are smooth, without grooves (Küchler 2000; and also his personal information and unpublished photographs), which correspond well to the diagnosis of $P$. globularis. The co-occurrence of both species in the same beds also suggests that $P$. nuciformis may be one of the numerous morphotype of P. globularis.

Among the numerous species of Porosphaera (e.g. Stolley 1892; Hinde 1904; Brünnich Nielsen 1929; Senowbari-Daryan et al. 2011) only some are well diagnosed. Most of them (e.g. P. plana (Stolley, 1892), P. semiglobularis (Stolley, 1892), P. universa Brünnich Nielsen, 1929 and P. cerasi Brünnich Nielsen, 1929) are rare Cretaceous species, based upon body form or size of pores. Both features are variable in P. globularis and it cannot be excluded that some of these specimens are its younger synonymus. However, their revision is hampered by the lack of data on their basal skeleton. Porosphaera plana (Stolley) was described by Małecki (1989, p. 216, pl. 1, fig. 18) from the Kraków area, but these specimens are missing and their skeleton cannot

Text-fig. 3. Porosphaera globularis (Phillips, 1829) from the Campanian of Poland. A1-A5 - Bonarka. A1 - ULIa/Bo1. A2, A3 - view of the same specimen ULIa/Bo2; A4 - ULIa/Bo3; A5 - section trough specimen ULIa/B04 with two crossing borings. B1-B2, Bibice. B1, section trough specimen ULIa/Bi1with two borings. B2 - ULIa/Bi2. C1-C3 - specimens from Iwanowice; C1 - section trough specimen ULIa/11with three crossing borings. C2 - ULIa/I2. C3 - ULIa/I3. D1-D2 - specimens from Poskwitów. D1 - ULIa/Ps1. D2 - ULIa/Ps2. E1-E2 - specimens from Wierzchowisko. E1 - ULIa/W1. E2 - ULIa/W2. F1-F2 - specimens from Jeżówka 1. F1 - ULIa/J1. F2 - ULIa/J2. G1-G2 - specimens from Jeżówka 2. G1 - ULIa/Je1. G2 - ULIa/Je2. H1-H2 - specimens from Pniaki. H1 - ULIa/Pn1. H2 - ULIa/Pn2. I1-I3 - specimens from Biała Wielka. I1 - ULIa/Bw1. I2 - ULIa/Bw2 J1-J3 - specimens from Zbyczyce; J1 - section trough specimen ULIa/Z1with a three crossing borings. J2 - ULIa/Z2. J3 - ULIa/Z3. K1-K3 - specimens from Wola Więcławska. K1 - ULIa/Ww1. K2 - ULIa/WW2. L1-L2 - specimens from Falniów. L1 - ULIa/F1. L2 - ULIa/F2. M1-M3 - specimens from Komorów. M1, M2 - ULIa/K1. M3 - ULIa/K2. N1-N3 - specimens from Poradów. N1 - ULIa/Po1. N2 - ULIa/Po2. O1-O6 - specimens from Mielnik; O1 - ULIa/M1. O2 - ULIa/M2. O3, O4 - view of the same specimen ULIa/M4. O5, O6 - ULIa/M4. Some borings arrowed 
be examined. The loose ectosomal spicules, critical for the taxonomy of recent species of Minchinellidae (Vacelet 1981, 1991; Könnecker and Freiwald 2005), have usually not been found in fossil sponges. In our
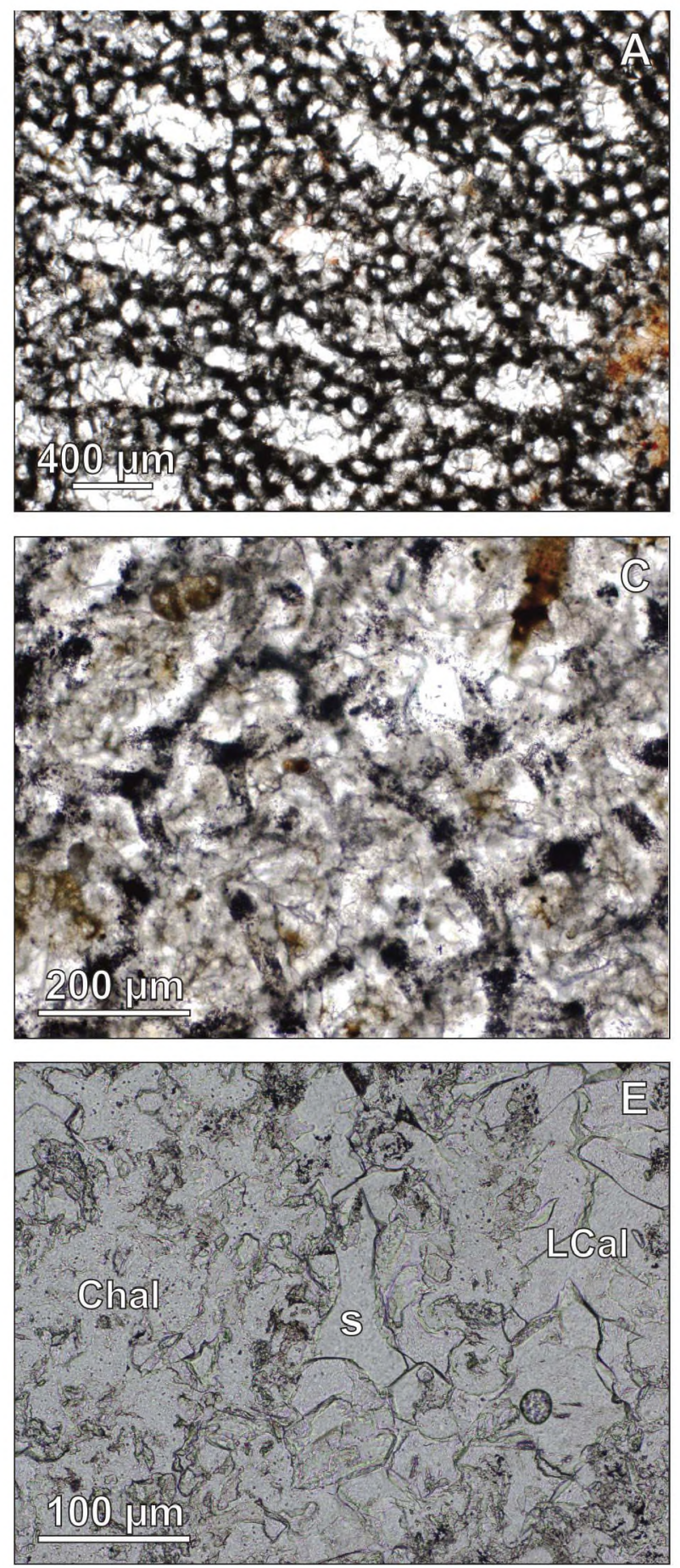

material these spicules are also missing. Tetractines described by Małecki (1989, pl. 1, fig. 2a, b) as ectosomal spicules are spicules from the outer layer of the basal skeleton.
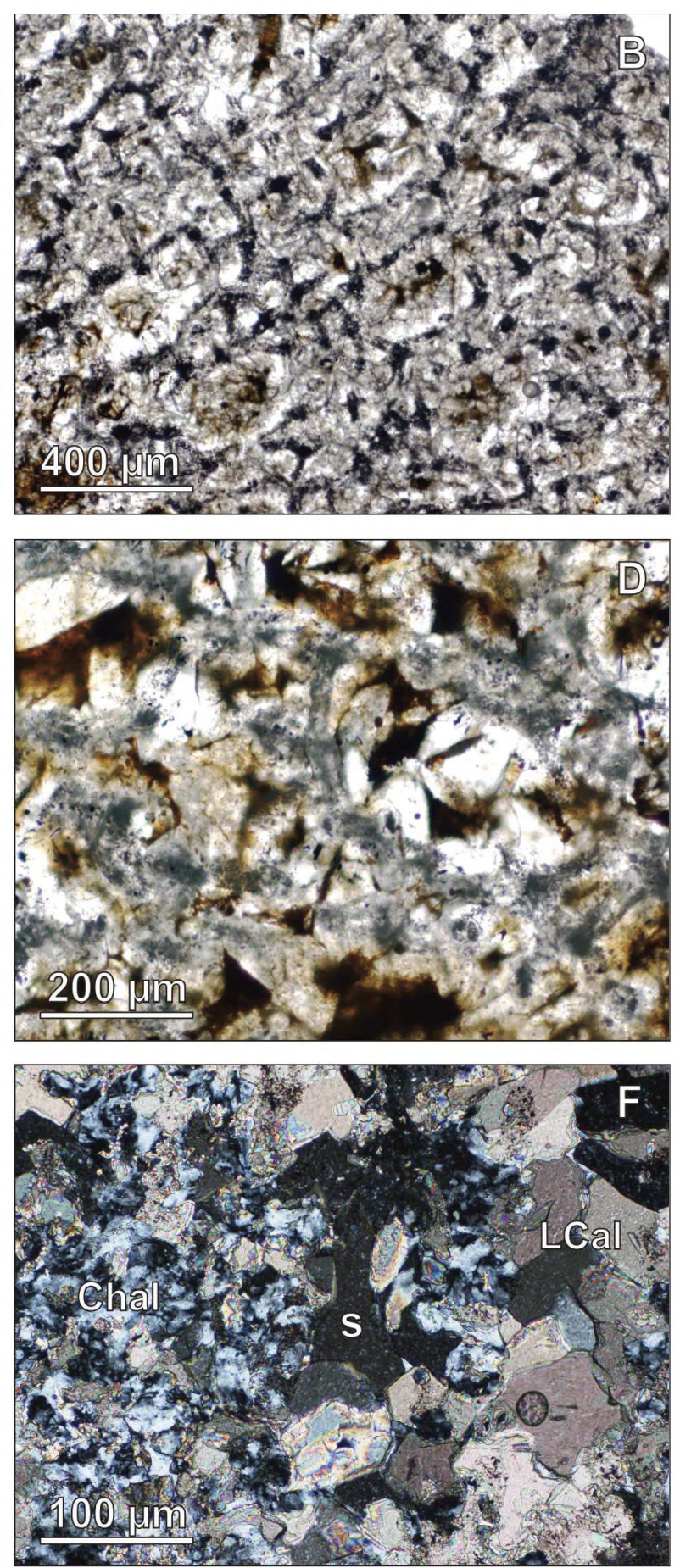

Text-fig. 4. Skeleton of specimen ULI/256 Bonarka (A-D) and specimen ULL/M3 from Mielnik (E, F) observed in thin sections. A-internal structure of the skeleton shows the typical radiating canals. B, C - tetractines from external part of basal skeleton. D - poorly preserved tetractines masked by late calcite. E- internal structure of the poorly visible skeleton, strongly calcitized and silicified. F - the same, crossed nicols. Chal - chalcedone; LCal - late calcite; $s$ - calcareous 

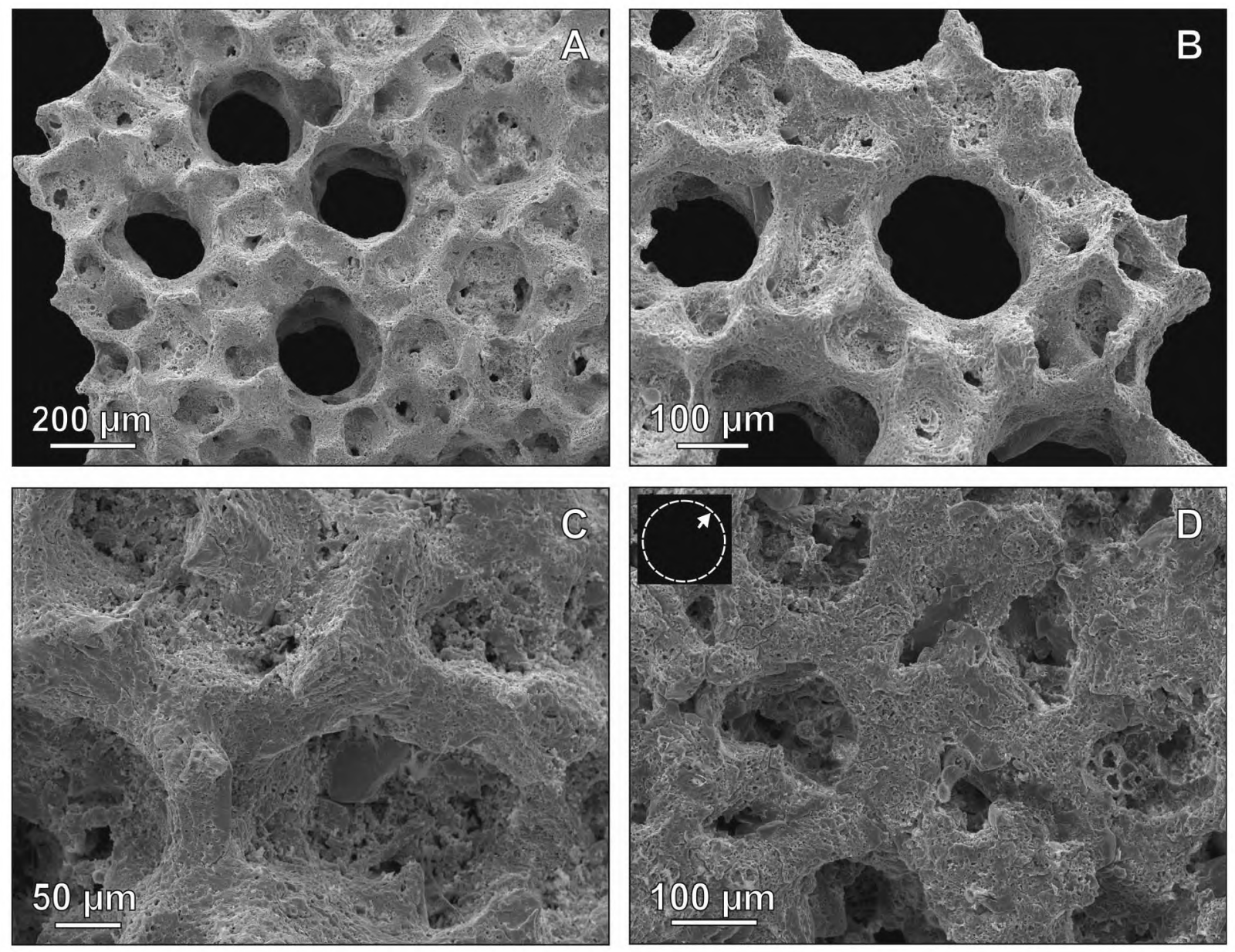

Text-fig. 5. SEM images showing the structure of outer layer of basal skeletal of Porosphaera globularis (Phillips, 1829) from Mielnik, ULIa/M5. A-C - external surface of outer layer of basal skeletal with fused tetractines; locally visible their free apical actines pointing outwards. D - inner surface (arrowed on scheme) of outer layer of basal skeleton; visible fused basal actines of tetractines; surface of tetractines less regular as on fig. A-C, due to the growth of late calcite

The ectosomal skeleton of $P$. globularis was described only by Hinde (1904, pl. 2, figs 2, 7, 10), which seems to be a unique phenomenon in the fossil representatives of Minchinellidae.

EPIFAUNA AND BORINGS: The epifauna, represented by bryozoans, octocorals (Text-fig. 7) and probably serpulids, is extremely rare; it was found only on six large specimens.

In the material studied ca. $17 \%$ of the sponges have cylindrical borings, with slightly rounded terminations (Text-fig. 3). Such borings are common in $P$. globularis from other localities (e.g. Nestler 1961; Wilmsen et al. 2012) and are interpreted as the mobile domicile of sipunculan worms (Neumann et al. 2008). Małecki (1989) described borings only in large specimens (more than $15 \mathrm{~mm}$ in diameter), while we noted them also on smaller ones, $8-10 \mathrm{~mm}$ in diameter. Ac- cording to Hurcewicz (1960) and Małecki (1989), borings often pierce through the sponge's body. Our observations agree with Rigaud et al. (2009), that borings never go through the entire length of a specimen. Borings are often very deep which causes the remaining part of the sponge skeleton to be thinner (ca. $2 \mathrm{~mm}$ ) so that it could be easily destroyed (Text-fig. 3As). The wide conical shape of borings illustrated by Małecki (1989, pl. 2, fig. 4), is a result of damage of the sponge's skeleton around the terminal part of a boring. In some specimens $2-3$, even 5 borings occur (Textfig. $3 \mathrm{~B}_{1}, \mathrm{C}_{1}, \mathrm{~J}_{1}, \mathrm{M}_{3}$ ). Usually one boring is larger than the other or the others. Differently oriented borings inside the sponge skeleton may be connected and form an irregular system. Sometimes in transverse section only a small part of this system is visible, which seems to be one winding boring (Text-fig. $3 \mathrm{~A} 5, \mathrm{~J}_{1}$; see also Małecki 1989, pl. 2, fig. 5). 
OCCURRENCE: Poland (Kraków, Miechów and Szczekociny area; uppermost Santonian, Lower and Middle Campanian; Mielnik, Lower Campanian; Kornica, ?Lower Campanian), England (southern England, Turonian-Campanian - after Hinde 1904 and Wood 2002; Norfolk, Lower Maastrichtian - after Peak and
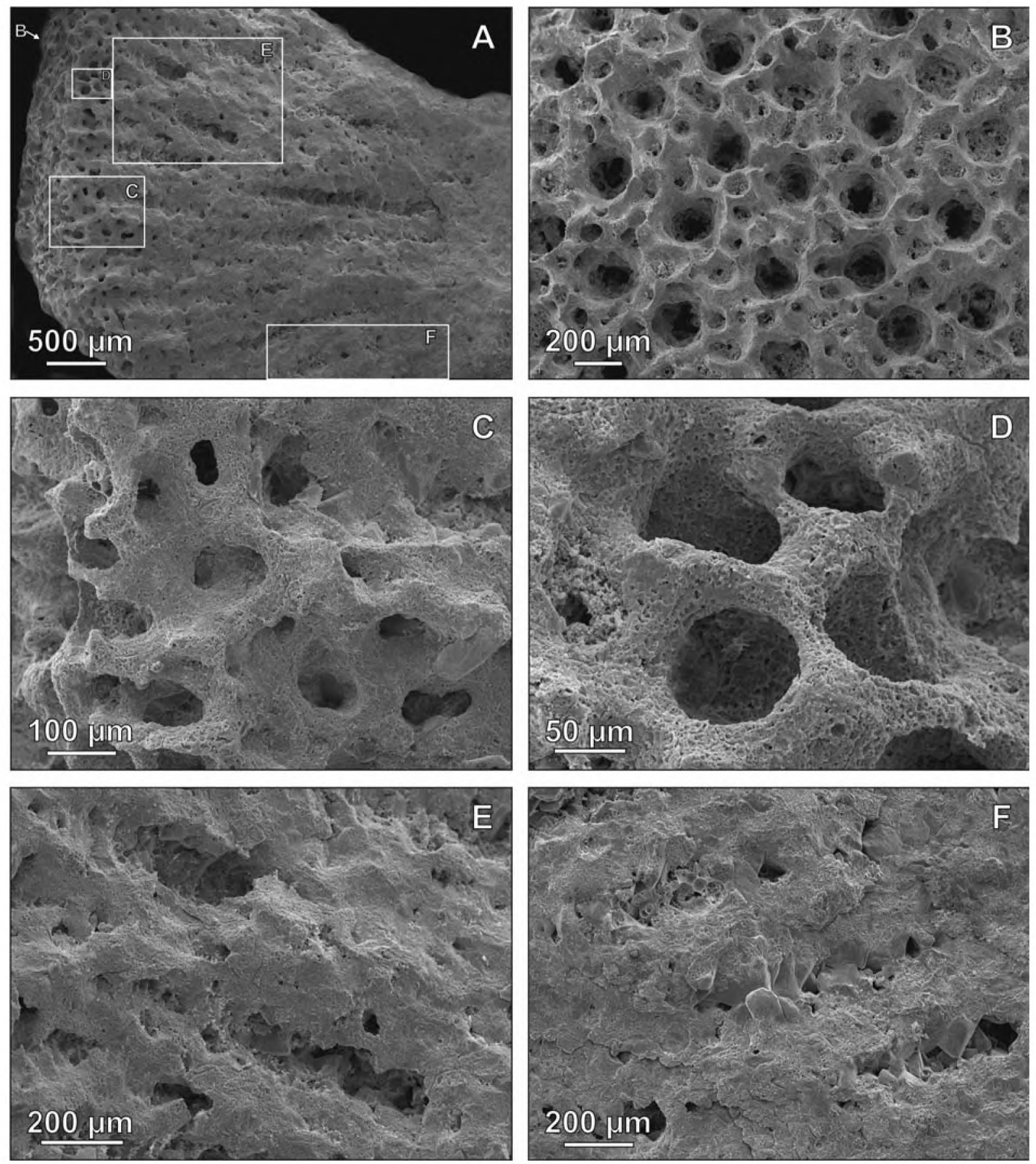

Text-fig. 6. SEM images showing the skeletal of Porosphaera globularis (Phillips, 1829) from Mielnik, ULIa/M5. A-cross-section of basal skeleton; radiating structures are poorly visible; B - external surface of outer layer of basal skeletal. C - details of outer layer of skeleton ca. $400 \mu \mathrm{m}$ thick, without late sparry calcite. D - enlarged fragment of skeleton from outer layer. E - inner layer of basal skeleton; single tetractines not visible, probably masked by filling of interspace by a late sparry calcite. F - close-up of the central part of the basal skeleton; visible radiating structures cemented by late sparry calcite, tetractines not visible 

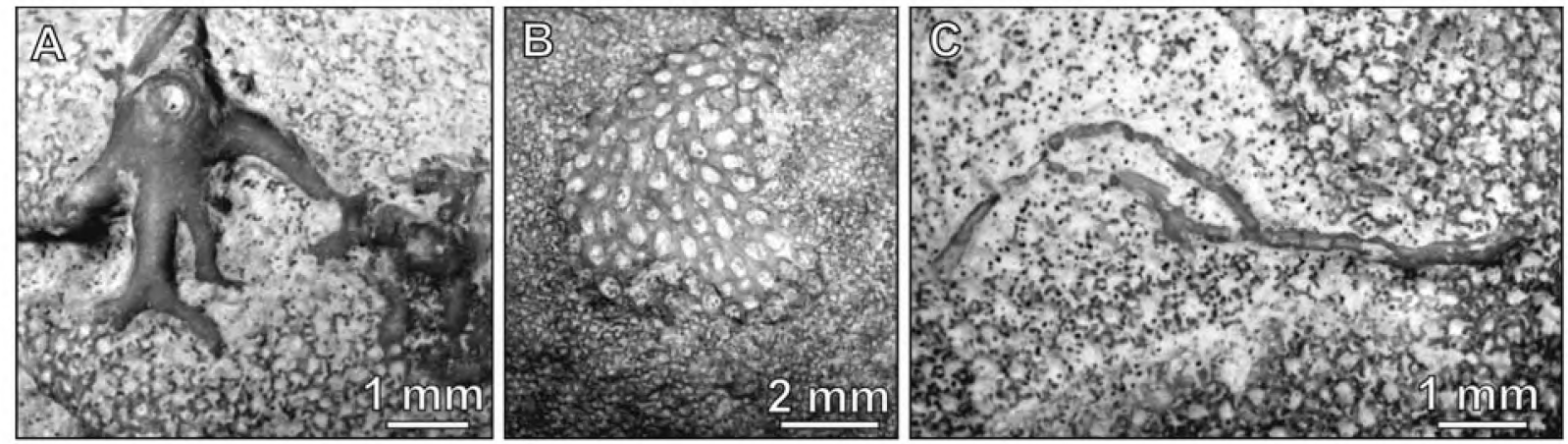

Text-fig. 7. Epifauna on the surface of Porosphaera globularis (Phillips, 1829). A-Moltkia sp., calcified attached base of octocoral comprising a root-like, multibranching structure. B, C-bryozoans; B - sheet-like encrusting colony; C-poorly preserved runner-like encrusting form (? Voigtopora sp.); all specimens are from the Miechów Synclinorium

Lepage and Lepage 2011; Campanian - after Brünnich and Nielsen 1929, with additional comments by Gaspard 2002; south-western France, Santonian-Lower Campanian - after Termier and Termier 1985b), Spain (Lower, Middle and Upper Campanian - after Küchler, personal information); Netherlands (Upper Maastrichtian - after Neumann et al. 2008); Germany (Helgoland, Turonian - after Stiihmer et al. 1986; Westphalia, Middle Campanian - after Giers 1964 with additional comments by Kaplan et al. 1996, Walaszczyk 1997 and Jagt et al. 2004; Stapelburg, Lower Campanian after Ulbrich 1974; Peine and Lehrte region near Hannover, Lower Saxony, Lower Campanian - after Niebuhr 1995; Misburg, Lower Saxony, Upper Campanian - after Neumann et al. 2008 and Niebuhr 1996; Rügen, Lower Maastrichtian - after Nestler 1961, Neumann et al. 2008, Reich and Frenzel 2002; Hemmoor, SchleswigHolstein, Upper Maastrichtian - after Neumann et al. 2008); Denmark (Alaborg, Upper Maastrichtian - after Lauridsen and Surlyk 2008; Mons Klint, Upper Campanian and/or Maastrichtian - after Brünnich Nielsen 1929 with additional comments by Surlyk et al. 2013 and Ogg and Hinnov 2012; Stevns Klint, Upper Maastrichtian - after Hansen and Surlyk 2014; Lower Paleocene - after Bjerager and Surlyk 2007); Belgium (Upper Campanian - after Jagt and Michels 1986; Maastrichtian - after Jagt et al. 2009); Czech Republic (Upper Turonian and/or Lower Coniacian - after Frič 1889 with additional comments by Čech et al. 1980), Crimea (after Naidin, unpublished data); Russia (Vol'sk and Khvalynsk areas, Lower Maastrichtian - after Pervushov 1998 and Naidin, unpublished data); Khazakhstan (Embi and Kobda areas, Lower Maastrichtian after Naidin, unpublished data); northern Causasus (Lower Campanian - after Naidin, unpublished data); Tajikistan (Lower Maastrichtian - after Naidin, unpublished data); Iran (Khur area, Central Iran, ?Lower Maastrichtian - after Wilmsen et al. 2012).

\section{DISCUSSION}

Porosphaera globularis ranges through most of the Upper Cretaceous of Europe, and usually occurs in distinct horizons of various thickness (e.g. Küchler 2000; Mortimore et al. 2001; Wilmsen et al. 2012). Hinde (1904) noted that the largest specimens of Porosphaera globularis occur in the Upper Santonian Uintacrinus socialis and Marsupites testudinarius zones in southern England, in which zones they are sufficiently common to serve as guide fossils.

Porosphaera globularis is also most common in the Campanian (e.g. Giers 1964; Küchler 2000; unpublished data of D.P. Naidin) and Maastrichtian (e.g. Nestler 1961; Pervushov 1998; Mortimore et al. 2001, Reich and Frenzel 2002; Wilmsen et al. 2012; unpublished data of D.P. Naidin) (Text-fig. 8).

Clearly, $P$. globularis is most common in the Lower Campanian. In Germany, it is known from the Sphenoceramus patootensiformis-Cataceramus dariensis/ Sphaeroceramus sarumensis inoceramid zones of Lower Saxony (Niebuhr 1995; for details and correlation of inoceramid zonation see Walaszczyk 1997) and Sachsen-Anhalt (Ulbrich 1974). Küchler reported P. globularis from the Scaphites hippocrepis III/Menabites spp. ammonite Zone of Spain (personal information), which corresponds to the lower part of the Cataceramus dariensis/Sphaeroceramus sarumensis inoceramid Zone of Walaszczyk (1997). From the uppermost Lower Campanian, $P$. globularis is known from the Cataceramus beckumensis Zone (for stratigraphical details see Walaszczyk 1997; Jagt et al. 2004; Keutgen 2011) of the Zeven Vegen Member of the lower part of the Gulpen Formation in Belgium (Jagt and Michels 1986).

From the Middle Campanian, P. globularis is noted in Belgium, in the upper part of the Belemnitella mucronata/Belemnitella woodi belemnite Zone (Keutgen 
2011) of the Zeven Vegen Member (Jagt and Michels 1986), which corresponds to the 'Inoceramus' azerbaydjanensis/'I.' vorhelmensis inoceramid Zone (Walaszczyk 1997; Jagt et al. 2004). In the same interval $P$. globularis was recognized in Westphalia (Giers 1964; for stratigraphical details see Kaplan et al. 1996; Jagt et al. 2004). Küchler (pers. com) noted the species in the Nostoceras (Bostrochyceras) polyplocum ammonite Zone in Spain, which corresponds to the Cataceramus subcompressus inoceramid Zone of Walaszczyk (2004). Similarly P. globularis was noted in Lower Saxony (Nieburh 1996; Neumann et al. 2008) in the Conulus vulgaris/Micraster stolleyi echinoid Zone, which corresponds to the C. subcompressus inoceramid Zone of Walaszczyk et al. (2008). In the upper part of the Middle Campanian ('Inoceramus' tenuilineatus Zone), $P$. globularis is known so far only from the Miechów Synclinorium.

In the Upper Campanian $P$. globularis was recognized only in Spain (Küchler 2000) in the Nostoceras (Nostoceras) hyatti ammonite Zone, which corresponds to the 'Inoceramus' inkermanensis Zone of Walaszczyk (2004).

P. globularis is also known from the Campanian of France (Termier and Termier 1985b; Brünnich and Nielsen 1929) but biostratigraphical details of the report are unknown.

In the white chalk of the glaciotectonic masses on the Norfolk coast in eastern England an interval with relatively abundant $P$. globularis is called the 'Porosphaera beds' and was used for local stratigraphical correlation of the various masses (Wood 1967; Johansen and Surlyk 1990; for detailed stratigraphy see Mortimore et al. 2001). According to Christensen et al. (2000) the Porosphaera Beds in England belong to the Belemnella pseudobtusa and B. obtusa belemnite Zones which correspond to the Endocostea typica inoceramid Zone (lower part of the Lower Maastrichtian) (see Keutgen et al. 2012). A mass-occurrence of $P$. globularis in the lower Maastrichtian white chalk was noted in Rügen Island, Germany (Nestler 1961; Reich and Frenzel 2002). Specimens illustrated by Reich and Frenzel (2002) derive from the V brachiopod Zone sensu Steinich (1965). Representatives of the foraminiferal genus Stensioeina were noted only in the lower part of this zone (Reich and Frenzel 2002). The last appearance of this genus is a good proxy of the lower/upper Maastrichtian boundary (Dubicka and Peryt 2012). These data suggest that the beds with $P$. globularis in Rügen are younger than the 'Porosphaera beds' in England.

In the Santonian-Campanian Ulster White Limestone succession in Northern Ireland $P$. globularis is recorded from each of the members (see Fletcher and Wood 1978 for details); it has not been recorded from the overlying Lower Maastrichtian limestones but its apparent absence is almost certainly due to the difficulty of observing it in sections that are not air-weathered. There is therefore no evidence to show whether or not the Porosphaera beds abundance event is represented in Northern Ireland.

In Poland, the stratigraphically equivalent deposits of the white chalk facies Porosphaera beds in eastern England crop out near the town of Pińczów, in the Miechów Synclinorium (sandy marls of the Endocostea typica Zone), and near Kłudzie and Dziurków in the middle Vistula River valley (opoka of the E. typica Zone after Walaszczyk 2004; Belemnella obtusa Zone after Keutgen et al. 2012; Remin 2012). In spite of the rich literature devoted to these latter sections, $P$. globularis has never been noted from there and is unknown to the authors (observations of A.J and E.ŚG). Similarly, still higher Lower Maastrichtian deposits, which could be equivalent to the beds with $P$. globularis from Rügen, and which are known from the Miechów Synclinorium and from the middle Vistula River valley, have never yielded $P$. globularis.

$P$. globularis has not been noted in the Upper Maastrichtian of Poland whereas it is well known from this interval in north-western Europe. Neumann et al. (2008) have noted $P$. globularis in the Belemnitella juniorBelemnitella kazimiroviensis belemnite Zone (Keutgen 2011) of Maastricht (Netherlands). In the uppermost Maastrichtian, this sponge was found in Stevns Klint (Denmark) in the Belemnitella junior-Belemnitella kazimiroviensis Zone (Brünnich and Nielsen 1929; Hansen and Surlyk 2014). The species is also known from other Maastrichtian sections in this part of Europe, as e.g., Germany (Schleswig-Holstein region after Neumann $e t$ al. 2008), Belgium (Lixhe, province of Liege after Jagt et al. 2009) and Denmark (Alaborg, Mons Klint after Brünnich Nielsen 1929, for stratigraphical details see Surlyk et al. 2013), however, its precise stratigraphic locations from there are uncertain.

We also had the opportunity of studying the collection of P. globularis from various localities in Russia, Ukraine, Kazakhstan and Tajikistan, housed in the Museum of the University of Lódź, and given to the Museum by the late prof. Dimitr P. Naidin. Unfortunately, the specimens from those collections have only rough locality and stratigraphical data. However, on the basis of Naidin's unpublished notes it can be inferred that representatives of this species occur in northern Donbass (?Turonian), Crimea (Lower Maastrichtian), northern Caucasus (Upper Campanian), western Kazakhstan (Lower Maastrichtian of Emba and Khobda, Asia), and 


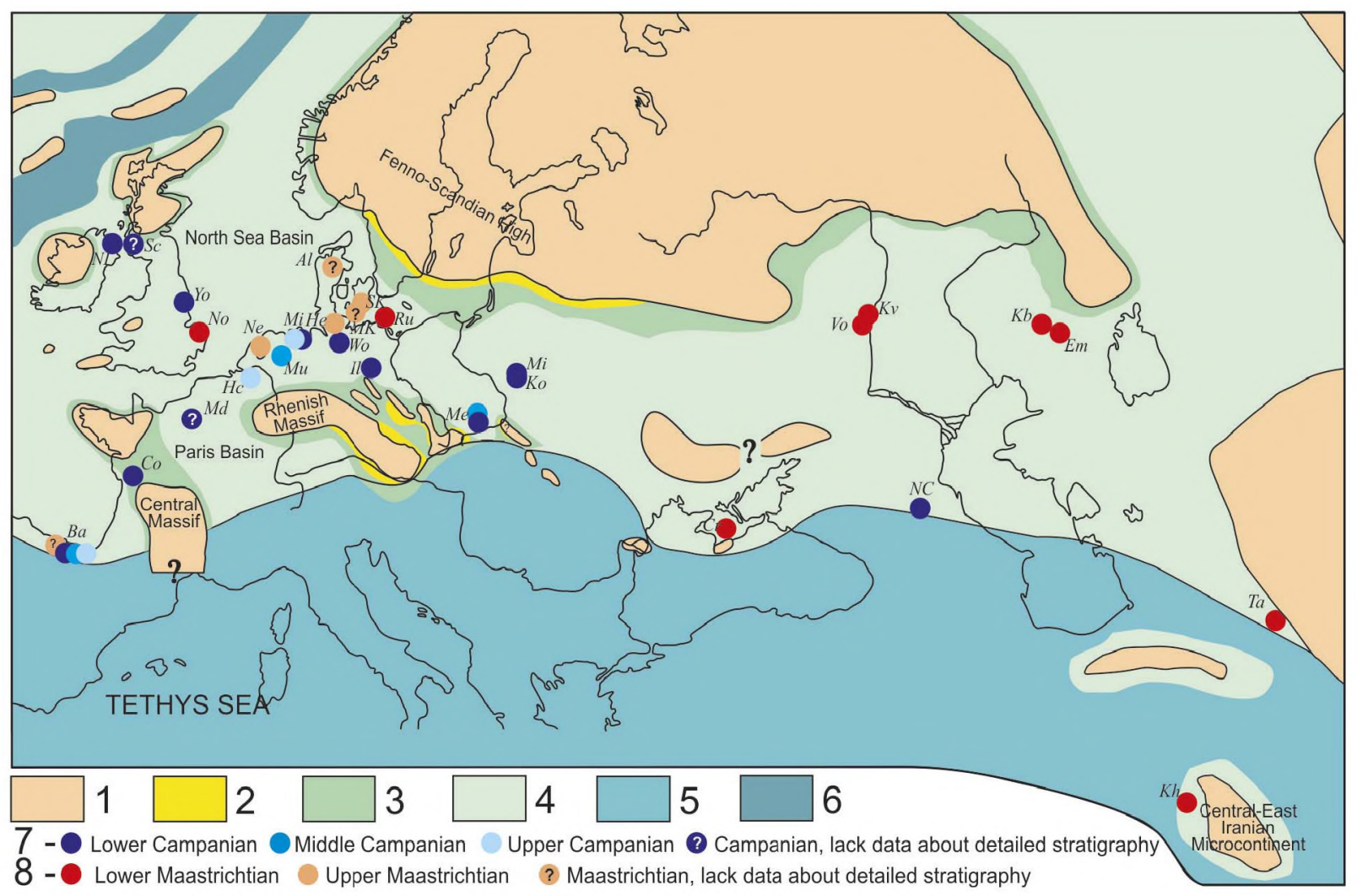

Text-fig. 8. Localities with Porosphaera globularis (Phillips, 1829) on Campanian - Maastrichtian palaeogeography of the European area (paleogeography after Naidin 1959; Kauffman 1973; Ziegler 1990; Wilmsen et al. 2012). North European Province: 1 - Land areas; 2 - Deltaic, coastal and shallow-marine siliciclastic facies; 3 - Near-shore facies (sands, marls, carbonate marls, marly carbonates, carbonates); 4 -Shallow marine, dominantly carbonate marine facies (marly carbonates, carbonates, chalk, white chalk, carbonate shales); Mediterranean Province: 5 - area extent without facies characteristics; Atlantic rift: 6 - including future development; Localities with $P$. globularis: 7 - Campanian localities: Ko - Kornica, eastern Poland; Mi - Mielnik, eastern Poland, Me-Kraków-Miechów-Szczekociny area, southern Poland; Ba -Barranca, nothern Spain; Co - Cognac area, Charente, France; Md - Meudon, France; Hc - Haccourt, Belgium, Mi - Misburg, Lower Saxony, Germany, Mu - Münsterland, Westfalen, Germany; Wo - Wolfenbüttel, Lower Saxony, Germany; Il - Isenburg, Saxony-Anhalt, Germany; Yo - Yorkshire, England; Sc - Scotland, ?Coniacian - ?Campanian; NI - Northem Ireland; NC - northern Causasus; 8 - Maastrichtian localities: Al - Alaborg area, Denmark; MK - Mønt Klint, Denmark; SK - Stevns Klint, Denmark; Em - Embi, Khazakhstan; Kh - Khur area, Central Iran; Kb-Kobda, Kazkhstan; No - Norfolk, England; Ru - Rügen, Germany; Ne - Netherlands; He - Hemmor, Schelzwik-Holstein, Germany Kv - Khvalinsk, Russia; Vo - Vol'sk, Russia; Ta - Tajikistan

Tajikistan ('Senonian' Maastrichtian). With these occurrences included, the (probably) Early Maastrichtian finds of $P$. globularis from Iran (Wilmsen et al. 2012), although still far away to the south-east, are already much closer to other occurrences of this species in the eastern part of the boreal epicontinental sea of Europe (Text-fig. 8).

\section{CONCLUSIONS}

In the Campanian of extra-Carpathian Poland, the recognized representative of the genus Porosphaera Steinmann is Porosphaera globularis. The specimens from the Campanian of Poland are characterized by high intraspecific variability, similar to that of specimens from other parts of Europe.
In the Cretaceous of the Miechów Synclinorium, Porosphaera globularis occurs in the following stratigraphical intervals, defined by inoceramid bivalve zones: uppermost Santonian-basal Campanian (Sphenoceramus patootensiformis Zone to Sphaeroceramus sarumensis-Cataceramus dariensis Zone), parts of the Middle Campanian (upper 'Inoceramus' azerbaydjanensis/'T'. vorhelmensis to 'I'. tenuilineatus Zone), and lowermost Upper Campanian (Sphaeroceramus pertenuiformis Zone); being apparently absent from the intervals between.

In the Cataceramus beckumensis Zone P. globularis occurs in only one section (Mielnik). In the Miechów Synclinorium these interval is represented by hardgorund.

Intervals with $P$. globularis from the Campanian and Maastrichtian of Europe do not correlate with 
each other. The occurrence of $P$. globularis in the deposits of similar or the same age in different areas of Europe seems to be associated with similar environmental conditions prevailing in the various intervals of the Late Cretaceous. It suggests that the Porosphaerarich intervals may have rather limited geographical extent and, consequently, do not represent events of high correlation potential. However, they may still be used successfully in local-scale correlations.

\section{Acknowledgements}

The authors are greatly indebted to Anna and Tadeusz Jurkowscy and Kamil Kowalski for their help in the fieldwork, to Józef Drywulski for allowing the fieldwork in the Mielnik Quarry, to Ireneusz Walaszczyk, Marcin Machalski and Christopher Wood for valuable comments, to Thomas Küchler for information and unpublished photos of specimens from Spain, to Birgit Niebuhr, Finn Surlyk and John Jagt for some stratigraphical information, to Sarah King, Curator of Natural Sciences at York Museums Trust, for photos and information about specimen from the YM collection, to Marek Wróbel for help with SEM images and to Waldemar Obcowski for graphical suggestions, to Adam Borowski for donating some specimens from Mielnik. Support was given by the National Science Center (grant number: PRO-2011/01/N/ST10/07717) and the statutory fund for young scientists from the Institute of Geological Sciences of the Jagiellonian University (project number: S/MND/WBiNoZ/NNG/3/2013), the statutory fund of the Laboratory of Geology of the University of Lódź (statutory project 506/844) and the fund of the Institute of Geology, of the University of Warsaw (BSt 170202).

\section{REFERENCES}

Alexandrowicz, S. 1954.Turonian of the southern part of the Cracow Upland. Acta Geologica Polonica, 4, 361-391. [In Polish]

Alexandrowicz, S. and Radwan, D. 1992. Stratigraphy and glacitectonic deformation of the white chalk of Kornica. Przeglad Geologiczny, 40, 296-301. [In Polish]

Barczyk, W. 1956. On the Upper Chalk Deposits on Bonarka near Cracow. Studia Societatis Scientiamm Toruniensis, 3 (2), 1-23.

Bieda, F. 1933. Sur les Spongiaires siliceux du Sénonien des environs de Cracovie. Annales Societatis Geologorum Poloniae, 9, 1-41.

Bjerager, M. and Surlyk, F. 2007. Benthic palaeoecology of Danian deep-shelf bryozoan mounds in the Danish Basin. Palaeogeography, Palaeoclimatology, Palaeoecology, 250, 184-215.
Brünnich Nielsen, K. 1929. Kalksvampe i Danmarks Senonium og Danium. Meddelelser fra Dansk Geologisk Forening , 7, 323-342.

Christensen, W.K. 1976. Paleobiogeography of Late Cretaceous belemnites of Europe. Paläontologische Zeitschrift, 50, 113-129.

Christensen, W.K., Hancock, J.M., Peake, N.B. and Kennedy, W.J. 2000. The base of the Maastrichtian. Bulletin of the Geological Society of Denmark, 47, 81-85.

Čech, S., Klein, V., Kř̌žž, J. and Valečka, J. 1980. Revision of the Upper Cretaceous stratigraphy of the Bohemian Cretaceous Basin. Věstník Ústredního ústavu geologického, 55(5), 277-296.

Dubicka, Z. and Peryt, D. 2012. The Lower/Upper Maastrichtian boundary interval in the Lublin Syncline (SE Poland, Boreal realm): new insight into foraminiferal stratigraphy. Newsletters on Stratigraphy, 45 (2), 139-150.

Fletcher, T.P. and Wood, C.J. 1978. Cretaceous Rocks. In: H.E. Wilson and P.I. Manning, Geology of the Causeway Coast, Volume 2. HMSO, pp. 85-115.

Frič, A. 1889. Studien im Gebiete der böhmischen Kreideformation. IV. Die Teplitzer Schichten. Archiv für die naturwissenschaftliche Landesdurchforschung von Böhmen, 7 (2), 1-119.

Gaspard, D. 2002. Les Brachiopodes de la craie blanche de Meudon (Campanien supérieur) de la collection d'Orbigny (MNHN, Paris). Comptes Rendus Palevol, 1, 573-585.

Giers, R. 1964. Die Grossfauna der Mukronatenkreide (unteres Obercampan) in östlichen Münsterland. Fortschritte in der Geologie von Rheinland und Westfalen, 7, 213-294.

Gaździcka, E. 1981. Coccoliths and index foraminifera from the upper Cretaceous chalk of Mielnik region, Eastern Poland. Acta Palaeontologica Polonica, 26 (1), 73-84.

Gradziński, R. 1960. Przewodnik geologiczny po okolicach Krakowa. Wydawnictwa Geologiczne, Warszawa.

Hansen, T. and Surlyk, F. 2014. Marine macrofossil communities in the uppermost Maastrichtian chalk of Stevns Klint, Denmark. Palaeogeography, Palaeoclimatology, Palaeoecology, 399, 323-344.

Hart, M.B., Bailey, H.W., Crittenden, S., Fletcher, B.N., Price, R.J. and Swiecicki, A. 1989. Cretaceous. In: D.G. Jenkins and J.W. Murray (Eds), Stratigraphical Atlas of Fossil Foraminifera, second edition. Ellis Horwood Limited, Chichester, pp. 273-371.

Hinde, G.J. 1904. On the Structure and Affinities of the genus Porosphaera, Steinmann. Journal of the Royal Microscopical Society, London, 1-25.

Hurcewicz, H. 1960. Porosphaera from the Upper Cretaceous in the vicinity of Kraków. Acta Paleontologica Polonica, 5, 435-449. [In Polish with English summary]

Hurcewicz, H. 1966. Siliceous sponges from the Upper Cretaceous of Poland; Part I, Tetraxonia. Acta Paleontologica Polonica, 11, 15-129. 
Hurcewicz, H. 1989. Type: Porifera. In: Malinowska, L. (Ed.), Geology of Poland: Atlas guide and characteristics fossils part 2c, Mesozoic, Cretaceous. Wydawnictwa Geologiczne, Warszawa, pp. 218-235.

Jagt, J.W.M., Van Rijsselt, W. and Van Rijsselt, E. 2009. Opmerkelijke Luiks-Limburgse Krijtfossielen. Deel 14. Gegroefde sponsjes. Natuurhistorisch Maandblad, 98, 203-205.

Jagt, J.W.M. and Michels, G.P.H. 1986. Cardiotaxis heberti (Cotteau 1860) en Cardiaster granulosus (Goldfuss 1829) uit het onderste deel van de Formatie van Gulpen (BovenKrijt): paleobiologie, voorkomen en systematiek. Grondboor en Hamer, 40 (6), 185-205.

Jagt, J.W.M., Walaszczyk, I., Yazykova, E.A. and Zatoń, M. 2004. Linking southern Poland and Northern Germany: Campanian cephalopods, inoceramid bivalves and echinoids. Acta Geologica Polonica, 54 (4), 573-586.

Johansen, M.B. and Surlyk, F. 1990. Brachiopods and the stratigraphy of the Upper Campanian and Lower Maastrichtian Chalk of Norfolk, England. Palaeontology, 33, $823-872$.

Jurkowska, A. 2014. Inoceramid stratigraphy and depositional architecture of the upper part of the Upper Cretaceous. PhD Thesis 1-191. [In Polish]

Kaplan, U., Kennedy, W.J. and Ernst, G. 1996. Stratigraphie und Ammoniten faunen des Campan im südöstlichen Münsterland. Geologie und Paläontologie in Westfalen, 43, $1-133$.

Kauffman, E.G. 1973. Cretaceous Bivalvia. In: A.H. Hallam (Ed.), Atlas of Palaeobiogeography, 353-386. Elsevier; Amsterdam - London - New York.

Keutgen, N. 2011. The belemnite zonation of the uppermost Cretaceous in the Maastricht-Aachen-Liège, BrabantMéhaigne and Mons areas (Belgium, southeast Netherlands). Netherlands Journal of Geosciences - Geologie en Mijnbouw, 90 (2/3), 165-178.

Keutgen, N., Remin., Z. and Walaszczyk, I. 2012. Early representatives of the belemnite genus Belemnella (Cephalopoda) from the uppermost Campanian-Lower Maastrichtian of the Middle Vistula River section, central Poland. Acta Geologica Polonica, 62 (4), 535-559.

Koch, W. 1977. Stratigraphie der Oberkreide in Nordwest Deutschland (Pompeckjsche Scholle). Teil 2. Biostratigraphie in der Oberkreide und Taxonomie von Foraminiferen. Geologisches Jahrbuch, Reihe A, 38, 11-123.

Könnecker, G. and Freiwald, A. 2005. Plectroninia celtica n. sp. (Calcarea, Minchinellidae), a new species of "pharetronid" sponge from bathyal depths in the northern Porcupine Seabight, NE Atlantic. Facies, 51, 53-59.

Küchler, T. 2000. Upper Cretaceous of the Barranca (Navarra, northern Spain); integrated litho-, bio- and event stratigraphy. Part II: Campanian and Maastrichtian. Acta Geologica Polonica, 50, 441-499.
Kudrewicz, R. and Olszewska-Nejbert, D. 1997. Upper Cretaceous „Echinoidlagerstätten“ in the Kraków area. $A n$ nales Societatis Geologorum Poloniae, 67, 1-12.

Langner, E. 1990. Wykształcenie facjalne i sedymentacja kredy piszącej w Kornicy. Praca magisterska, Archiwum IGP, Warszawa, 1-97. [In Polish]

Lauridsen, B.W. and Surlyk, F. 2008. Benthic faunal response to late Maastrichtian chalk-marl cyclicity at Rordal, Denmark. Palaeogeography, Palaeoclimatology, Palaeoecology, 269, 38-53.

Lepage, Y. and Lepage, J.J. 2011. Note sur un important effondrement de falaise aux Petites-Dalles, commune de Saint-Martin-aux-Buneaux (Seine-Maritime, France), au début de l'été 2010. Bulletin Sciences et Géologie Normandes, 3, 15-33.

Leszczyński, K. 1997. The Upper Cretaceous carbonate-dominated sequences of the Polish Lowlands. Geological Quarterly, 41 (4), 521-532.

Leszczyński, K. 2012. The internal geometry and lithofacies pattern of the Upper Cretaceous-Danian sequence in the Polish Lowlands. Geological Quarterly, 56 (2), 363-386.

Matecki, J. 1989. The genus Porosphaera (Spongiae) from the Lower Campanian sediments in the vicinity of Krakow. Bulletin of the Polish Academy of Sciences, Earth Sciences, 37, 205-217.

Mączyńska, S.S. 1968. Echinoids of the genus Micraster L. AGASSIZ from the Upper Cretaceous of the CracowMiechów area. Prace Muzeum Ziemi, 12, 87-168.

Mortimore, R.N., Wood, C.J. and Gallois, R.W. 2001. British Upper Cretaceous Stratigraphy, Geological Conservation Review Series, No. 23, Joint Nature Conservation Committee, Peterborough, 1-558.

Narkiewicz, M. and Dadlez, R. 2008. Geologiczna regionalizacja Polski - zasady ogólne i schemat podziału w planie podkenozoicznym i podpermskim. Przegląd Geologiczny, 56, 391-397. [In Polish]

Naidin, D.P. 1959. On the paleogeography of Russian Platform during the Upper Cretaceous epoch. Stockholm Contributions in Geology, 3, 127-138.

Neumann, C., Wisshak, M. and Bromley, R.G. 2008. Boring a mobile domicile: an alternative to the conchicolous life habit. In: M. Wisshak and L. Tapanila (Eds), Current Developments in Bioerosion. Springer, Berlin, Heidelberg, New York, pp. 307-328.

Nestler, H. 1961. Spongien aus der weißen Schreibkreide (Unt. Maastricht) der Insel Rügen (Ostsee). Paläontologische Abhandlungen, 1, 1-70.

Niebuhr, B. 1995. Fazies-Differenzierungen und ihre Steuerungsfaktoren in der höheren Oberkreide von SNiedersachsen/Sachsen-Anhalt (N-Deutschland). Berliner Geowissenschaftliche Abhandlungen, Reihe A, 174, 1131.

Niebuhr, B. 1996. Die Scaphiten (Ammonoidea, Ancylocer- 
atina) des höheren Obercampan der Lehrter Westmulde östlich Hannover (N-Deutschland), Berliner Geowissenschaftliche Abhandlungen, Reihe F, 18, 267-287.

Ogg, J.G. and Hinnov, L.A. 2012. Cretaceous. In: F. Gradstein, J. Ogg, M. Schmitz and G. Ogg (Eds), The Geologic Time Scale, pp. 793-842.

Olszewska, D. 1987. Wykształcenie facjalne i sedymentacja kredy piszącej w Mielniku nad Bugiem. Praca Magisterska, Archiwum UW, pp. 1-133.

Olszewska, D. 1990. Belemnites from the Upper Cretaceous Chalk of Mielnik (eastern Poland). Acta Geologica Polonica, 40 (1), 111-128.

Olszewska-Nejbert, D. and Świerczewska-Gladysz, E. 2011. Campanian (Late Cretaceous) hexactinellid sponges from the white chalk of Mielnik (Eastern Poland). Acta Geologica Polonica, 61, 383-417.

Panow, E. 1934. Sur la stratigraphie du crétacé des environs de Cracovie. Annales Societatis Geologorum Poloniae, 10, 577-585. [In Polish]

Peake, N.B. and Hancock, J.M. 1961. The Upper Cretaceous of Norfolk. Transactions of the Norfolk and Norwich Naturalists Society, 19, 293-339.

Peake, N.B. and Hancock, J.M. 1970. The Upper Cretaceous of Norfolk (reprinted with corrigenda and addenda with new map). Transactions of the Norfolk and Norwich Naturalists Society, 19, 293-339.

Pervushov, E.M. 1998. Late Cretaceous ventriculitid Sponges of the Volga Region. Tom 2. Geologii SGU, Saratov; GosUNTs Kolledzh. [In Russian]

Peryt, D. 1981. Planktonic foraminifers and the age of chalk from Mielnik (East Poland). Bulletin de l'Académie Polonaise des Sciences, Série des Sciences de la Terre, 29 (2), 137-142.

Phillips, J. 1829. Illustrations of the geology of Yorkshire, or a description of the strata and organic remains. Part 1. The Yorkshire Coast. (York: privately printed).

Počta, F. 1903. Beiträge zur Kenntnis der Calcispongien aus der Kreideformation. Bulletin international de l'Académie des Sciences de Bohéme, 8, 1-6.

Pożaryski, W. 1960. An outline of stratigraphy and palaeogeography of the Cretaceous in the Polish Lowlands. Part. II. Prace Instytutu Geologicznego, 30, 377-418.

Pożaryski, W. 1974. Tectonics. Part 1. Polish Lowlands. In: Pożaryski, W. (Ed.), Geology of Poland IV, pp. 2-34. Wydawnictwa Geologiczne; Warszawa. [In Polish]

Pyrah, B.J. 1976. Catalogue of type and figured fossils in the Yorkshire Museum: Part 1. Proceedings of the Yorkshire Geological Society, 41, 35-47.

Reich, M. and Frenzel, P. 2002. Die Fauna und Flora der Rügener Schreibkreide (Maastrichtium, Ostsee). Archiv für Geschiebekunde, 3, 73-284.

Remin, Z. 2012. The Belemnella stratigraphy of the Campanian-Maastrichtian boundary; a new methodological and taxonomic approach. Acta Geologica Polonica, 62, 495533.

Rigaud, S., d'Errico, F., Vanhaeren, M., Vanhaeren, M. and Neumann, C. 2009. Critical reassessment of putative Acheulean Porosphaera globularis beads. Journal of Archaeological Science, 36 (1), 25-34.

Rutkowski, J. 1965. Senonian in the area of Miechów, southern Poland. Rocznik Polskiego Towarzystwa Geologicznego, 35 (1), 3-53. [In Polish with English summary]

Schönfeld, J. 1990. Die Stratigraphie und Ökologie benthischer Foraminiferen im Schreibekreide-Richtprofil von Lägerdorf/Holstein. Geologisches Jahrbuch, Reihe A, 117, 3-151.

Schulz, M.-G., Ernst, G., Ernst, H. and Schmid, F. 1984. Coniacian to Maastrichtian stage boundaries in the standard section for the Upper Cretaceous white chalk of NW Germany (Lägerdorf-Kronsmoor-Hemmoor): Definitions and proposals. Bulletin of the Geological Society of Denmark, 33, 203-215.

Senowbari-Daryan, B., Fürsich F, and Wilmsen, M. 2011. Porosphaera (Porifera), a globular sponge from the Upper Jurassic of the central Iran. Rivista Italiana di Paleontologia e Stratigrafia, 117 (3), 451-462.

Smoleński, J. 1906. Dolny senon w Bonarce. I. Glowonogi i Inoceramy. Rozprawy Wydzialu Matematyczno- Przyrodniczego Akademii Umiejętności, Kraków, Seria $B, 6$, $1-34$.

Steinich, G. 1965. Die artikulaten Brachiopoden der Rügener Schreibkreide (Untermaastricht). Paläontologische $A b_{-}$ handlungen, A, Paläozoologie 2 (1), 1-220.

Steinmann, G. 1878. Über fossile Hydrozoen aus der Familie der Coryniden. Palaeontographica A, 25, 101-124.

Stolley, E. 1892. Die Kreide Schleswig-Holsteins. Mitteilungen aus dem Mineralogischen Institut der Universität Kiel, 1, 191-309.

Stühmer, H.H., Schmid, F. and Spaeth, C. 1986. Fossilien Helgolands, Teil 2: Oberkreide. Niederelbe-Verlag, Otterndorfer Verlagsdruckerei H. Huster KG Helgoland/Otterndorf.

Surlyk, F., Rasmussen S.L., Boussaha, M., Schiøler, P., Schovsbo, N.H., Sheldon, E., Stemmerik, L. and Thibault, N. 2013. Upper Campanian-Maastrichtian holostratigraphy of the eastern Danish Basin. Cretaceous Research, 46, 232-256.

Termier, H. and Termier, G. 1985a. Les Spongiaires du Crétacé normand. Bulletin trimestriel de la Société Géologique de Normandie et des Amis du Muséum du Havre, 72 (3), 7-89.

Termier, H. and Termier, G. 1985b. Sponges of Santonian and Campanian age along motorway-A10 (France). Cretaceous Research, 6, 143-155.

Ulbrich, H. 1974. Die Spongien der Ilsenburg-Entwicklung 
(Oberes Unter-Campan) der Subherzynen Kreidemulde. Freiberger Forschungshefte, Reihe C, 291, 1-121.

Vacelet, J. 1981. Éponges hypercalcifiées ("Pharétronida", "Sclérosponges") des cavités des récifs coralliens de Nouvelle-Calédonie. Bulletin du Muséum National d'Histoire Naturelle, Paris 4e sér, Section A, 3 (2), 313-351.

Vacelet, J. 1991. Recent Calcarea with a reinforced skeleton. In: J. Reitner and H. Keupp (Eds), Fossil and recent sponges. Springer-Verlag, Berlin, pp. 252-265.

Walaszczyk, I. 1992. Turonian through Santonian deposits of the Central Polish Uplands; their facies development, inoceramid paleontology and stratigraphy. Acta Geologica Polonica, 42 (1-2), 1-122.

Walaszczyk, I. 1997. Biostratigraphie und Inoceramen des oberen Unter-Campan und unteren Ober-Campan NordDeustchlands. Geologie und Paläontologie in Westfalen, 49, 5-117.

Walaszczyk, I. 2004. Inoceramids and inoceramid biostratigraphy of the Upper Campanian to basal Maastrichtian of the Middle Vistula River section, central Poland. Acta Geologica Polonica, 54 (1), 95-168.

Walaszczyk, I., Cobban, W.A., Wood, Ch. and Kin, A. 2008. The "Inoceramus" azerbaydajensis fauna (Bivalvia) and its value for chronostratigraphic calibration of the European Campanian (Upper Cretaceous). Bulletin de l'Institut Royal des Sciences Naturelles de Belgique, 78, 229-238.

Wilmsen, M., Fürsich, F.T. and Majidifard, M.R. 2012.
Porosphaera globularis (Phillips, 1829) (Porifera, Calcarea) from the Maastrichtian of the Farokhi Formation of Central Iran. Cretaceous Research, 33, 91-96.

Wilson, H.E. and Robbie, J.A. 1966. Geology of the country around Ballycastle. Memoirs of the Geological Survey Northern Ireland, Belfast: HMSO.

Wollemann, A. 1901. Die Fauna des Senons von Biewende bei Wolfenbüttel. Jahrbuch der Königlich Preussischen Geologischen Landesanstalt und Bergakademie, 21, 1-30.

Wood, C.J. 1967. Some new observations on the Maestrichtian Stage in the British Isles. Bulletin of the Geological Survey of Great Britain, 27, 271-288.

Wood, R. 2002. Sponges. In: Smith, A.B., Batten, D.J. (Eds), Fossils of the Chalk. Palaeontological Association Field Guides to Fossils, second ed., 2, pp. 27-41.

Zapałowicz-Bilan, B., Pilarz, M., Machaniec, E. 2009. Micropaleontological biostratigraphy of the Upper Cretaceous and Miocene deposits in "Bibice" borehole (Kraków area). Geologia, 35, 95-103. [In Polish with English summary]

Ziegler, P.A. 1990. Geological Atlas of Western and Central Europe (2nd ed.). 1-293. Shell Internationale Petroleum Maatschappij B.V.; Mijdrecht, The Hague, Amsterdam.

Żelaźniewicz, A., Aleksandrowski, P., Buła, Z., Karnkowski, P.H., Konon, A., Oszczypko, N., Ślączka, A., Żaba, J., Żytko, K. 2011. Regionalizacja Tektoniczna Polski. Komitet Nauk Geologicznych PAN, Wroclaw. [In Polish]

Manuscript submitted: $15^{\text {th }}$ October 2014

Revised version accepted: $30^{\text {th }}$ December 2014 